\title{
Poultry by-product meal as dietary protein source for dourado, Salminus brasiliensis: an economic appraisal
}

\author{
Renan Antunes Donadelli ${ }^{1 \oplus}$, Fredy Armando Aguilar Aguilar ${ }^{1 \oplus}$, Daniel Yokoyama Sonoda ${ }^{2} \odot$, José Eurico Possebon Cyrino ${ }^{1 *}(\odot)$
}

IUniversidade de São Paulo/ESALQ - Depto. de Zootecnia, Av. Pádua Dias, 11 - 13418-900 - Piracicaba, SP - Brasil. Instituto de Pesquisas e Educação Continuada em Economia e Gestão de Empresas - I-PECEGE; R. Alexandre Herculano, 120 - T6 - 13418-445 - Piracicaba, SP - Brasil

*Corresponding author <jepcyrino@usp.br>

Edited by: Gerson Barreto Mourão

Received July 26, 2017

Accepted December 11, 2017

\begin{abstract}
The dourado, Salminus brasiliensis, a large, carnivorous, Neotropical, Characin, is highly regarded for fish farming and sport fishing alike. However, studies on the farming and husbandry of dourado are still scarce. This study evaluated the performance of dourado fed diets formulated so as to contain increasing levels of poultry by-product meal as a replacement for fish meal and aimed to identify the maximum level of replacement to maximize profit. The trial was set up in a closed recirculation system with controlled water quality (temperature $27^{\circ} \mathrm{C}$, dissolved oxygen $6.5 \mathrm{mg} \mathrm{L}^{-1}, \mathrm{pH} 7.4$, and ammonia $0.25 \mathrm{mg} \mathrm{L}^{-1}$ ). Juvenile fish were stocked in tanks in a completely randomized design, acclimatized to system conditions and experimental diets, and then fed twice a day for 66 days with extruded, nutritionally complete diets $40 \%$ digestible protein and $4020 \mathrm{kcal} \mathrm{kg}^{-1}$ digestible energy), formulated to contain $0,20,40,60$, 80 or $100 \%$ poultry meal as a surrogate protein source for fish meal. Performance parameters - average weight gain, specific growth rate, feed consumption, feed conversion rate, protein efficiency rate, productive value of protein, energy retention rate, survival rate - did not differ $(p>0.05)$. To minimize the effects of influential data, the robust regression method was used and profit maximization analysis revealed that replacing $33.3 \%$ of dietary fishmeal by poultry by-product meal maximizes profit in the farming of dourado.

Keywords: fish nutrition, alternative feedstuffs, economic evaluation
\end{abstract}

\section{Introduction}

The dourado, Salminus brasiliensis (Cuvier, 1816), is a large, carnivorous, Neotropical migratory Characin from the Prata river basin. As a result of overfishing and damming of rivers for hydropower operations, natural stocks of dourado are becoming increasingly endangered (Pompeu, 2012; Weingartner and Zaniboni-Filho, 2010). Additionally, dourado is considered a highly promising aquaculture species given its rapid initial growth and high commercial value (Weingartner and Zaniboni-Filho, 2010). Nonetheless, information on the farming and husbandry of dourado is scarce, at best. Because of its carnivorous feeding habits, the species requires high dietary protein contents, which can increase feeding costs owing to the need for ingredients high in protein (Borghetti et al., 1990; Cyrino et al., 2012).

Even though fish meal (FM) can be obtained from fish of no commercial value or processing wastes, production of FM is based on wild caught fish, especially marine species (Hertrampf and Piedad-Pascual, 2000). Overexploitation of fishery resources and the decline of land fishery products (FAO, 2016) have prompted an increase of circa $55 \%$ in the price of FM (US $\$ 1,143.00$ in July 2009 to US $\$ 1,650.00$ per metric ton in June 2016; FAO, 2016) which translates into increases in the production costs of farmed carnivorous fish. Given this scenario, one of the major research areas of fish nutrition is the study of alternative ingredients to FM, aiming to reduce production costs and overfishing (Hardy, 2010).
The Brazilian poultry industry is the third largest in the world (IndexMundi, 2014). The rendering of poultry industry wastes yield feather meal, poultry by-product meal, poultry fat, and other by-products which can be used in animal nutrition as surrogate protein sources (Hertrampf and Piedade-Pascual, 2000). It has been shown that poultry byproduct meal (PBM), for instance, can be used as the sole protein source in diets of farmed piavuçu Leporinus macrocephalus (Characiformes: Anostomidae) without hampering performance (Schwertner et al., 2013). This study is aimed at determining the maximum level of replacement of FM by PBM that maximizes profit without harming the performance of juvenile dourado fed diets containing increasing levels of PBM as a substitute for dietary FM.

\section{Materials and Methods}

\section{Fish, diets and experimental conditions}

Juvenile dourado $(12.00 \pm 0.58 \mathrm{~g})$ were stocked in $24,300-\mathrm{L}$ plastic tanks (12 fish per tank) housed in a closed loop system with controlled temperature $(27.0$ $\left.\pm 1.0^{\circ} \mathrm{C}\right)$, in a completely randomized design $(\mathrm{n}=4)$, acclimatized to system conditions and experimental diets for 10 days, fasted for $24 \mathrm{~h}$, weighed and then fed to apparent satiation, twice a day (08h00 and 16h00) for 66 days with extruded, nutritionally complete diets formulated to contain increasing levels of PBM as surrogate protein source to FM $(100 \% \mathrm{FM} 0 \% \mathrm{PBM}$; 80\%FM20\%PBM; 60\%FM40\%PBM; 40\%FM60\% PBM; $20 \%$ FM80\%PBM; and 0\%FM100\%PBM) on a dietary 
digestible protein basis, according to digestibility coefficients reported in the literature (e.g. Braga et al., 2008; Borghesi et al., 2009).

Feed-grade salmon FM and PBM were ground, sieved $(\varnothing=0.5 \mathrm{~mm})$, analyzed for proximate composition, mixed with soybean oil and $20 \%$ water (weight basis), extruded in a single screw extruder (Inbramaq PQ-30m; Imbramaq, Ribeirão Preto, SP, Brazil) and oven dried (forced air; $50{ }^{\circ} \mathrm{C} ; 24 \mathrm{~h}$ ). Experimental diets were stored in plastic bags. Diets were formulated to be isonitrogenous (40\% digestible protein), isoenergetic (4020 $\mathrm{kcal} \mathrm{kg}^{-1}$ digestible energy) (DE and DP index from Braga et al., 2008; Borghesi et al., 2009), and supplemented with lysine (2.25\% total protein) to meet the species' requirements (Dairiki et al., 2013) (Table 1).

System water temperature $\left(26.8 \pm 2.2{ }^{\circ} \mathrm{C}\right)$, dissolved oxygen $\left(6.5 \pm 0.7 \mathrm{mg} \mathrm{L}^{-1}\right), \mathrm{pH}(7.4 \pm 0.2)$, and electrical conductivity $\left(2.6 \pm 0.1 \mathrm{mS} \mathrm{cm}{ }^{-1}\right)$ were evaluated by Horiba U-50 probe, and ammonia $(0.25 \pm 0.25$ $\mathrm{mg} \mathrm{L^{-1 }}$ ) by colorimetric test (LabconTest ${ }^{\circledR}$ ). Data were collected twice a week and kept within suitable limits for the species (Weingartner and Zaniboni-Filho, 2010).

\section{Performance and body composition}

Initial and final weight of fish and feed consumption were recorded for each experimental unit for determination of the performance parameters as follows: average weight gain $(\mathrm{g}):$ AWG $=$ (final average weight initial average weight); specific growth rate $\left(\% \mathrm{~d}^{-1}\right)$ : SGR $=[100 *(\ln$ final body weight $-\ln$ initial body weight $) /$ experimental period (days)]; feed conversion rate $(\mathrm{kg}$ of feed ${ }^{*} \mathrm{~kg}$ of body weight $\left.{ }^{-1}\right): \mathrm{FCR}=$ feed consumption $(\mathrm{g}$, as fed basis) / weight gain (g); feed index (\% of average weight $)=($ feed consumption $/ 12 / 66)(g) /[($ average final weight (g) + initial average weight (g)/ / 2] * 100; survival rate $(\%)=[$ (initial number of fish - number of dead fish) / (initial number of fish) * 100].

Prior to the start of the experiment, 20 fish were randomly sampled for determination of the initial body composition. At the end of the feeding period fish were weighed and three fish per replicate were sampled. Carcasses of sampled fish were ground coarsely, freeze dried and then finely ground to pass through a $1 \mathrm{~mm}$ screen for determination of body composition (AOAC, 1999) at a commercial laboratory. The protein efficiency ratio, protein productive value, and energy retention were calculated as follows: protein efficiency ratio (g crude protein in the body ${ }^{*} \mathrm{~g}$ consumed crude protein $^{-1}$ ): PER = weight gain (g)/ consumed crude protein (g); protein productive value (\%): PPV $=100 *$ [(final body weight $(\mathrm{g}) *$ crude protein in final body weight (\%)) - (initial body weight $(\mathrm{g}) *$ crude protein in initial body weight $(\%))] /$ (feed intake $(\mathrm{g})$ * crude protein in feed (\%)); energy retention (\%): ER $=100 *$ [(final body weight $(\mathrm{g}){ }^{*}$ gross energy in final body weight $\left(\mathrm{kcal} \mathrm{kg}^{-1}\right)$ - (initial body weight $(\mathrm{g}) *$ gross energy in initial body weight $\left(\mathrm{kcal} \mathrm{kg}^{-1}\right)$ ] / consumed gross energy (kcal kg-1).

Data were submitted to ANOVA $(\alpha=0.05)$ in a completely randomized design, after testing for homogeneity of variances (Levene test) and normality of residues (Shapiro-Wilk test) with the aid of an SAS program

Table 1 - Experimental diets formulation and composition.

\begin{tabular}{|c|c|c|c|c|c|c|}
\hline \multirow{2}{*}{ Ingredient, \% } & \multicolumn{6}{|c|}{ Diets/treatments } \\
\hline & $100 \% F M 0 \%$ PBM & $80 \% F M 20 \%$ PBM & $60 \%$ FM40\%PBM & 40\%FM60\%PBM & 20\%FM80\%PBM & 0\%FM100\%PBM \\
\hline $\mathrm{FM}^{1}$ & 65.4 & 52.3 & 39.2 & 26.2 & 13.1 & 0.0 \\
\hline $\mathrm{PBM}^{2}$ & 0.0 & 12.6 & 25.2 & 37.9 & 50.5 & 63.1 \\
\hline Starch & 19.8 & 21.1 & 21.2 & 22 & 22.7 & 23.5 \\
\hline Celluloses & 3.1 & 2.9 & 3.3 & 3.1 & 2.9 & 2.9 \\
\hline Soy oil & 10.4 & 9.7 & 9.3 & 8.7 & 8.2 & 7.6 \\
\hline Lysine & 0 & 0 & 0 & 0.35 & 0.75 & 0.93 \\
\hline $\mathrm{BHT}^{3}$ & 0.02 & 0.02 & 0.02 & 0.02 & 0.02 & 0.02 \\
\hline Premix ${ }^{4}$ & 1.0 & 1.0 & 1.0 & 1.0 & 1.0 & 1.0 \\
\hline \multicolumn{7}{|l|}{ Composition } \\
\hline $\mathrm{DM}^{5}, \%$ & 97.8 & 97.7 & 97.7 & 98.0 & 97.9 & 97.8 \\
\hline $\mathrm{DE}^{6}, \mathrm{kcal} \mathrm{kg}^{-1}$ & 4252 & 4229 & 4181 & 4164 & 4140 & 4116 \\
\hline $\mathrm{DP}^{7}, \%$ & 40.5 & 40.0 & 39.4 & 38.9 & 38.3 & 37.8 \\
\hline Fat, \% & 16.9 & 16.8 & 17.0 & 17.0 & 17.0 & 17.0 \\
\hline $\mathrm{CF}^{8}, \%$ & 3.0 & 3.0 & 3.5 & 3.5 & 3.5 & 3.6 \\
\hline Ash, \% & 10.5 & 10.4 & 10.4 & 10.3 & 10.2 & 10.1 \\
\hline Lysine, \% & 2.7 & 2.7 & 2.7 & 2.9 & 3.2 & 3.4 \\
\hline $\mathrm{GE}^{9}, \mathrm{kcal}^{\mathrm{kg}} \mathrm{-}^{-1}$ & 5081 & 5068 & 5058 & 5059 & 5129 & 5117 \\
\hline $\mathrm{CP}^{10}, \%$ & 43.1 & 42.9 & 42.8 & 42.8 & 42.9 & 42.7 \\
\hline
\end{tabular}

${ }^{1}$ Fish meal; ${ }^{2}$ Poultry by-product meal; ${ }^{3}$ Butylated hydroxytoluene; ${ }^{4}$ Mineral and vitamin mix (Campinas, SP, Brazil): Iron 15,000 mg kg-1; Copper 15,000 mg kg-1 ; Zinc $12,500 \mathrm{mg} \mathrm{kg}^{-1}$; lodine $375 \mathrm{mg} \mathrm{kg}^{-1}$; Manganese 12,500 mg kg-1; Selenium $87.5 \mathrm{mg} \mathrm{kg}^{-1}$; Cobalt $125 \mathrm{mg} \mathrm{kg}^{-1} ;$ Vitamin A 2,500,0000 IU kg-1; Vitamin D 600,000 IU $\mathrm{kg}^{-1}$; Vitamin E 37,500 IU kg-1; Vitamin K 3,750 mg kg ; Vitamin C 50,000 mg kg-1 Vitamin $\mathrm{B}_{1} 4,000 \mathrm{mg} \mathrm{kg}^{-1}$; Vitamin $\mathrm{B}_{2} 4,000 \mathrm{mg} \mathrm{kg}^{-1} ;$ Vitamin $\mathrm{B}_{6} 4,000 \mathrm{mg} \mathrm{kg}^{-1}$; Vitamin $\mathrm{B}_{12} 4,000 \mathrm{mg} \mathrm{kg}^{-1}$; Pantothenic acid 12,000 $\mathrm{mg} \mathrm{kg}^{-1}$; Biotin $15 \mathrm{mg} \mathrm{kg}^{-1}$; Folic acid 1,250 mg kg-1; Niacin 22,500 mg kg-1; Butil-hidroxi-toluen (BHT) 15,000 $\mathrm{mg} \mathrm{kg}^{-1}$; ${ }^{5}$ Dry Matter; ${ }^{6}$ Digestible energy; ${ }^{7}$ Digestible protein; ${ }^{8} \mathrm{Crude}$ fiber; ${ }^{9} \mathrm{G}$ ross energy; ${ }^{10} \mathrm{Crude}$ protein. 
(Statistical Analysis System, version 9.2). Data on the survival rate were transformed to arcsine of the square root before analysis. Variables bearing probability values close to the significance level for the test for the effects of treatment and homogeneity of variances were submitted to regression analysis, and adjusted to a second-degree polynomial model. This model was chosen because initial inspection of the data showed a U-shape dose-response relationship; posteriorly the adequacy of the model was proven by the lack of fit test. Significance of the estimated parameters and lack of fit was assessed at a $5 \%$ significance level. Outliers and influential data (DFFITS) were checked. Robust regression (M Estimation) was used to obtain unbiased estimates of the parameters (Huber, 1973). The maximum safe inclusion level (97.5\% of maximum response) was calculated according to Rawles et al. (2013).

\section{Economic evaluation}

An economic evaluation was performed by the profit maximization method, adapted from Varian (2010) and Griffiths et al. (1993). The contribution margin function $\left(\mathrm{L}_{\mathrm{ij}}\right)$, defined as the difference between income of the sale of the product $\left(\mathrm{R}_{\mathrm{ij}}\right)$ and the costs of production $\left(\mathrm{C}_{\mathrm{ij}}\right)$, was determined for each treatment (i) and replication $(\mathrm{j})$ :

$\mathrm{L}_{\mathrm{ij}}=\mathrm{S}_{\mathrm{ij}}-\mathrm{C}_{\mathrm{ij}}$

The income $\left(R_{i j}\right)$ is the price of the fish $(P=U S \$$ $\left.9.27 \mathrm{~kg}^{-1}\right)$ multiplied by the weight of the fish $\left(\mathrm{Y}_{\mathrm{ij}}\right)$ :

$\mathrm{R}_{\mathrm{ij}}=\mathrm{P} * \mathrm{Y}_{\mathrm{ij}}$

The cost $\left(\mathrm{C}_{\mathrm{ij}}\right)$ is the sum of the price of each feedstuff $\left(\mathrm{W} 1-\mathrm{FM}=\mathrm{US} \$ 2.74 \mathrm{~kg}^{-1}\right.$; W2 - PBM $=$ US $\$ 1.81$ $\mathrm{kg}^{-1}$ ) multiplied, respectively, by the quantity of feed consumed $\left(\mathrm{X}_{\mathrm{ij} 1}-\mathrm{FM} ; \mathrm{X}_{\mathrm{ij} 2}-\mathrm{PBM}\right)$ :

$\mathrm{C}_{\mathrm{ij}}=\left(\mathrm{W}_{\mathrm{ij} 1} * \mathrm{X}_{\mathrm{ij} 1}+\mathrm{W}_{\mathrm{ij} 2} * \mathrm{X}_{\mathrm{ij} 2}\right)$

The contribution margin equation can be rewritten as follows:

$\mathrm{L}_{\mathrm{ij}}=\mathrm{P} * \mathrm{Y}_{\mathrm{ij}}-\left[\left(\mathrm{W}_{\mathrm{ij} 1} * \mathrm{X}_{\mathrm{ij} 1}+\mathrm{W}_{\mathrm{ij} 2} * \mathrm{X}_{\mathrm{ij} 2}\right)\right]$

The contribution margin function based on the percentage of fishmeal in the diet can be represented as:

$\mathrm{L}_{\mathrm{ij}}=\mathrm{f}(\mathrm{i})$

wherein: $L_{i j}$ is the contribution margin and $f(i)$ the percentage of inclusion of FM and PBM $10,20,40,60,80$, and $100 \%$ ) in the diet.

For calculating the contribution margin (CM), only the protein sources used in the experimental diets were considered. This approach was adopted in the aim to remove any possible influence of the other dietary

ingredients, even though soybean oil and crystalline lysine are commonly used commercially in aquaculture feeds. The price of a $\mathrm{kg}$ of dourado was considered to be US $\$ 9.27$ according to fishery market reports (July 2013). To lessen the influence of outlier values in the analysis results, the working, functional formula used was the quadratic function estimated via the robust regression (M Estimation) method with the aid of the Statistical Analysis Software program 9.2 (SAS Institute; Cary, NC, USA) (Huber, 1973). Deriving and equalizing the profit function relative to the percentage of FM and PBM in the diet elicited the maximum, profitable replacement of FM by PBM.

\section{Results and Discussion}

The nutritional composition of the diets was similar and small differences in compositions resulted from variations in the composition of each combination of FM and PBM (Table 1). Lysine was supplemented with increasing levels of PBM (Table 1). The amino acid compositions of FM and PBM were similar and within the range of scientific literature reports (Table 2; AbdelWarith et al., 2001; Allan et al., 2000; Burel et al., 2000; Dairiki et al., 2013; Dozier and Dale, 2005; Meeker, 2009).

Initial $\mathrm{CP}$, fat, and ash in carcass composition were higher than values reported by Dairiki et al. (2013) and Teixeira et al. (2010), (Table 3). The final carcass composition was not influenced by increasing levels of PBM (Table 3). The crude protein level was similar to values reported by Dairiki et al. (2013) and Teixeira et al. (2010). However, fat contents herein reported were higher than values reported in both cited studies.

Feed consumption was similar across all treatments and no feed refusals were registered throughout the duration of the trial (Table 4). Protein productive value, ER and feed index were similar among fish fed ex-

Table 2 - Essential amino acid profile in fishmeal (FM), poultry byproduct meal (PBM) and whole dourado carcass.

\begin{tabular}{|c|c|c|c|}
\hline \multirow{2}{*}{ Essential amino acid } & $\mathrm{FM}^{1}$ & $\mathrm{PBM}^{1}$ & Dourado 2 \\
\hline & \multicolumn{3}{|c|}{$\%$ of Crude Protein } \\
\hline Lysine & 6.33 & 6.34 & 9.32 \\
\hline Methionine & 2.63 & 2.14 & 2.88 \\
\hline Methionine + Cysteine & 3.68 & 3.29 & 3.87 \\
\hline Threonine & 3.79 & 3.71 & 4.64 \\
\hline Tryptophan & 0.90 & 0.82 & 0.83 \\
\hline Arginine & 6.21 & 6.89 & 6.37 \\
\hline Glycine + Serine & 13.26 & 14.13 & 10.56 \\
\hline Valine & 4.64 & 4.73 & 5.13 \\
\hline Isoleucine & 4.17 & 4.32 & 4.61 \\
\hline Leucine & 6.69 & 7.48 & 8.21 \\
\hline Histidine & 2.40 & 2.72 & 2.68 \\
\hline Phenylalanine & 3.36 & 3.62 & 4.26 \\
\hline Phenylalanine + Tyrosine & 5.92 & 6.30 & 7.36 \\
\hline
\end{tabular}


Table 3 - Body composition of dourado (mean \pm SEM).

\begin{tabular}{|c|c|c|c|c|c|c|c|c|}
\hline Body composition & Initial & 100\%FM0\%РBM & 80\%FM20\%PBM & 60\%FM40\%PBM & 40\%FM60\%РBM & 20\%FM80\%PBM & 0\%FM100\%PBM & $p$-value \\
\hline $\mathrm{DM}^{1}, \%$ & 27.8 & $32.8 \pm 1.3$ & $31.6 \pm 0.8$ & $32.2 \pm 1.0$ & $31.6 \pm 0.2$ & $32.7 \pm 0.3$ & $31.2 \pm 0.6$ & 0.76 \\
\hline $\mathrm{CP}^{2}, \%$ & 20.0 & $18.3 \pm 0.7$ & $17.4 \pm 0.3$ & $17.4 \pm 0.2$ & $17.1 \pm 0.1$ & $18.1 \pm 0.2$ & $17.0 \pm 0.7$ & 0.42 \\
\hline Fat, $\%$ & 7.8 & $9.4 \pm 1.1$ & $8.8 \pm 0.5$ & $9.9 \pm 0.9$ & $8.9 \pm 0.1$ & $8.3 \pm 0.2$ & $8.4 \pm 1.3$ & 0.82 \\
\hline Ash, $\%$ & 6.1 & $4.1 \pm 0.2$ & $4.0 \pm 0.2$ & $3.9 \pm 0.1$ & $3.6 \pm 0.12$ & $3.8 \pm 0.1$ & $3.5 \pm 0.1$ & 0.19 \\
\hline $\mathrm{GE}^{3}, \mathrm{kcal} \mathrm{kg}^{-1}$ & 1127 & $1889 \pm 91.4$ & $1804 \pm 55.1$ & $1862 \pm 96.4$ & $1838 \pm 4.7$ & $1853 \pm 37.4$ & $1815 \pm 72.2$ & 0.97 \\
\hline
\end{tabular}

${ }^{1}$ Dry Matter; ${ }^{2}$ Crude Protein; ${ }^{3}$ Gross Energy.

Table 4 - Performance variables (mean \pm SEM) of juvenile dourado fed diets with different levels of fish meal and poultry by-product meal.

\begin{tabular}{|c|c|c|c|c|c|c|c|}
\hline Performance & 100\%FM0\%PBM & 80\%FM20\%PBM & 60\%FM40\%PBM & 40\%FM60\%PBM & 20\%FM80\%PBM & 0\%FM100\%PBM & $p$-value \\
\hline Feed consumption, $\mathrm{g}$ fish ${ }^{-1}$ & $68.0 \pm 3.4$ & $82.5 \pm 7.0$ & $73.8 \pm 3.1$ & $73.4 \pm 4.1$ & $62.7 \pm 6.7$ & $65.7 \pm 10.0$ & 0.3044 \\
\hline $\mathrm{AFW}^{1}, \mathrm{~g}$ & $90.6^{\mathrm{abc}} \pm 3.7$ & $106.8^{a} \pm 12.4$ & $101.6^{\mathrm{ab}} \pm 5.0$ & $93.3^{\mathrm{abc}} \pm 5.8$ & $80.9^{b c} \pm 5.9$ & $75.1^{c} \pm 9.2$ & 0.0696 \\
\hline$A W G^{2}, g$ & $78.7^{\mathrm{abc}} \pm 3.8$ & $94.6^{a} \pm 12.5$ & $89.9^{a b} \pm 5.0$ & $81.2^{\mathrm{abc}} \pm 5.8$ & $68.8^{\mathrm{bc}} \pm 5.8$ & $63.2^{c} \pm 9.1$ & 0.0692 \\
\hline $\mathrm{FCR}^{3}$ & $0.86^{a} \pm 0.01$ & $0.89^{a} \pm 0.06$ & $0.82^{\mathrm{a}} \pm 0.03$ & $0.91^{\mathrm{a}} \pm 0.02$ & $0.91^{\mathrm{a}} \pm 0.03$ & $1.04^{b} \pm 0.07$ & 0.0361 \\
\hline $\mathrm{PER}^{4}$ & $2.55^{\mathrm{ab}} \pm 0.03$ & $2.55^{\mathrm{ab}} \pm 0.17$ & $2.78^{a} \pm 0.08$ & $2.52^{\mathrm{ab}} \pm 0.04$ & $2.55^{\mathrm{ab}} \pm 0.08$ & $2.26^{b} \pm 0.15$ & 0.0675 \\
\hline $\mathrm{SGR}^{5}$ & $3.07^{\mathrm{ab}} \pm 0.09$ & $3.26^{a} \pm 0.19$ & $3.27^{\mathrm{a}} \pm 0.08$ & $3.08^{\mathrm{ab}} \pm 0.09$ & $2.86^{b} \pm 0.09$ & $2.75^{b} \pm 0.18$ & 0.0539 \\
\hline $\mathrm{PPV}^{6}$ & $42.2 \pm 2.0$ & $44.3 \pm 2.3$ & $44.7 \pm 2.9$ & $42.8 \pm 2.0$ & $43.1 \pm 2.0$ & $41.2 \pm 2.0$ & 0.8923 \\
\hline $\mathrm{ER}^{7}$ & $43.4 \pm 2.0$ & $42.6 \pm 4.2$ & $44.3 \pm 1.8$ & $42.5 \pm 2.3$ & $41.6 \pm 1.5$ & $38.6 \pm 2.6$ & 0.6876 \\
\hline Feed index & $2.00 \pm 0.04$ & $2.12 \pm 0.09$ & $1.98 \pm 0.05$ & $2.11 \pm 0.01$ & $2.02 \pm 0.18$ & $2.26 \pm 0.17$ & 0.3043 \\
\hline Survival rate, $\%$ & $97.9^{\mathrm{ab}} \pm 2.1$ & $93.8^{\mathrm{abc}} \pm 4.0$ & $97.9^{\mathrm{ab}} \pm 2.1$ & $100.0^{a} \pm 0.0$ & $87.5^{c} \pm 5.4$ & $89.6^{b c} \pm 4.0$ & 0.0995 \\
\hline
\end{tabular}

${ }^{1}$ Average fish weight; ${ }^{2}$ Average weight gain; ${ }^{3}$ Feed conversion rate; ${ }^{4}$ Protein efficiency rate; ${ }^{5}$ Specific growth rate; ${ }^{6}$ Protein productive value; ${ }^{7}$ Energy retention; $a, b, c$ Means with different superscripts differ $(p<0.05)$.

perimental diets. Average final weight, AWG, FCR, PER, SGR, and the survival rate of fish fed diets with lower replacement levels were generally higher than fish fed diets with higher levels of PBM (Table 4).

To perform calculations and analysis of the economic feasibility, only the price of FM and PBM were considered so as to have no influence of ingredients other than the protein source on the economical evaluation. The prices (US\$ $\mathrm{kg}^{-1}$ ) of FM, PBM, and juvenile dourado were, respectively, $\$ 2.74, \$ 1.81$, and $\$ 9.27$ (July 2013 exchange rate - R \$2.157 per US\$1.00). Prices of feedstuffs, weight gain, and feed consumption were considered for estimating gross revenue and costs including feed and the profit. The same was done regarding the performance parameters. Because influential data were detected in the model for contribution margin, the robust regression method was used for analysis of data. The quadratic model widely used for modelling dose-response studies showed adequate for the current data set, and was selected from the lack of fit analysis given the a better fit to the data compared to the linear model. However, this model tends to overestimate the response values. By analogy, using the quadratic model for modelling the data from this experiment could underestimate the replacement level (the levels of replacement can be higher). In an attempt to compensate for this overestimation, the maximum safe replacement level was set at $97.5 \%$ of maximum performance as described by Dozier et al. (2009), Rawles et al. (2013), and Tavernari et al. (2013). A maximum safe replacement level was thus defined and is shown as dashed lines on Figures 1 to 4 .

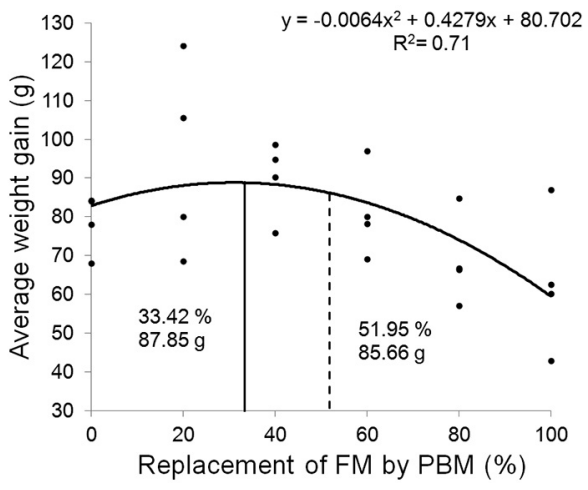

Figure 1 - Effect of replacement of fish meal (FM) by poultry by-product meal (PBM) on the average weight gain of juvenile dourado. Solid line is the maximun estimed response $(x=33.42$ $\% ; y=87.85 \mathrm{~g})$. Dashed line is $97.5 \%$ of maximun response $(x=$ $51.95 \% ; y=85.66 \mathrm{~g})$.

Average weight gain was higher for dourado fed $80 \%$ FM20\%PBM than fish fed 20\%FM80\%PBM and 0\%FM100\% PBM (Table 4). The same was registered for hybrid striped bass fed diets with $100 \%$ menhaden FM and $100 \%$ PBM supplemented with lys or met (Gaylord and Rawles, 2005). According to the model for AWG, optimal weight gain was $87.45 \mathrm{~g}$ at the $33.42 \%$ replacement level of FM by PBM. When considering the safe substitution level, the maximum replacement level increases to $51.45 \%$ and AWG decreases to 85.66 g. Similarly, increasing dietary PBM levels reduces the cost of the protein component of the feed from US\$ 


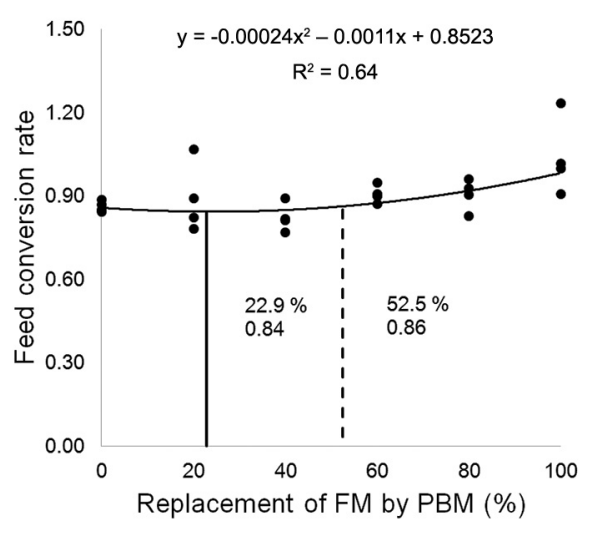

Figure 2 - Effect of replacement of fish meal (FM) by poultry byproduct meal (PBM) on the feed conversion ratio of juvenile dourado. Solid line is the maximun estimed response $(x=22.9 \%$; $y=0.84)$. Dashed line is $97.5 \%$ of maximun response $(x=52.5$ $\% ; y=0.86)$.

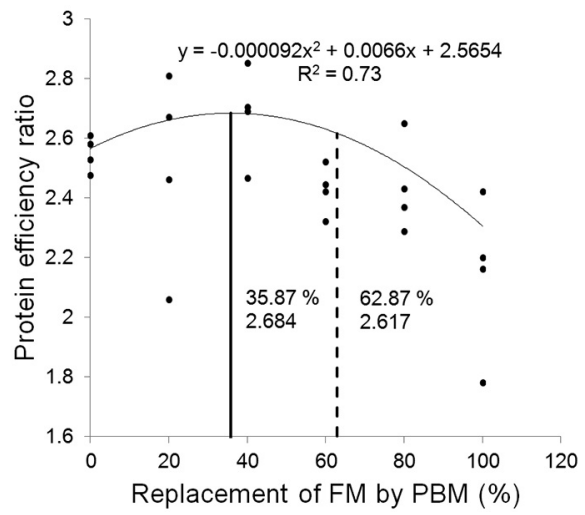

Figure 3 - Effect of replacement of fish meal (FM) by poultry byproduct meal (PBM) on the protein efficiency ratio of juvenile dourado. Solid line is the maximun estimed response $(x=35.87$ $\% ; y=2.684)$. Dashed line is $97.5 \%$ of maximun response $(x=$ $62.87 \% ; y=2.617$ ).

1.79 to US\$ $1.14 \mathrm{~kg}^{-1}$ when the equation from Figure 5 is used to calculate the protein cost in the ration. For largemouth bass (Micropterus salmouides), average final weight $(\mathrm{AFW}, \mathrm{FM}$ diet $=44.7 \mathrm{~g}$ vs. $\mathrm{PBM}$ diet $=42.7$ $\mathrm{g})$ and average harvest weight (FM diet $=57.3 \mathrm{~g} v \mathrm{~s}$. PBM diet $=57.6 \mathrm{~g}$ ) were not affected even at $100 \%$ of replacement of FM by PBM (Tidwell et al., 2005). On the contrary, mixed results were reported for hybrid sunshine bass. Gaylord and Rawles (2005) reported that the replacement of FM by PBM decreased weight gain (FM = $188 \mathrm{~g}$ vs. PBM $136 \mathrm{~g})$; however, the amino acids supplementation of PBM diet yielded fish growth rate similar to that of fish fed the FM diet. Rawles et al. (2009) reported that higher levels of PBM had no effect on percent weight gain /Generic $=1073 \%$ vs. $100 \%$ PBM $=987 \%$ ) and final weight $($ Generic $=932$

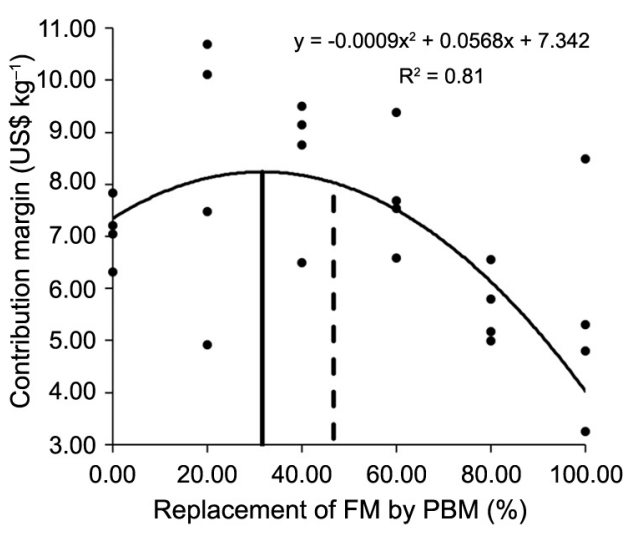

Figure 4 - Effect of replacement of fish meal (FM) by poultry byproduct meal (PBM) on the contribution margin of experimental production. Solid line is the maximum estimated response $(x=$ $31.60 \% ; y=$ US\$ $\left.8.24 \mathrm{~kg}^{-1}\right)$. Dashed line is $97.5 \%$ of maximum response $\left(x=46.70 \% ; y=\right.$ US\$ $\left.8.03 \mathrm{~kg}^{-1}\right)$.

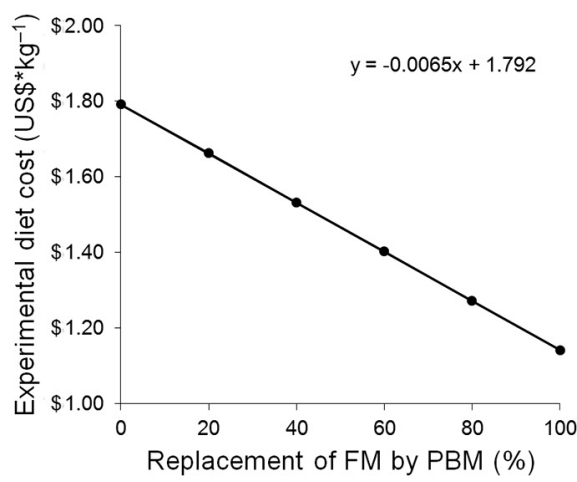

Figure $\mathbf{5}$ - Effect of replacement of fish meal (FM) by poultry byproduct meal (PBM) on experimental diet cost.

$\mathrm{g}$ vs. $100 \% \mathrm{PBM}=814 \mathrm{~g}$ ) using hybrid striped bass as the model species. In addition, when considering the inclusion of PBM in an available amino acid base, Rawles et al. (2006) reported that up to $35 \%$ PBM could be included in the diet without compromising the final weight (Generic $=787 \mathrm{~g}$ vs. $35 \% \mathrm{PBM}=775 \mathrm{~g}$ ) and the percent weight gain $/$ Generic $=800 \%$ vs. $35 \% \mathrm{PBM}=$ $779 \%$ ) of hybrid striped bass. This level of PBM inclusion reported by Rawles et al. (2006) is very close to the values for the maximum replacement levels for AFW, PER, and contribution margin reported in this study. For humpback grouper, percent weight gain and final weight were not affected even at $100 \%$ replacement (Shapawi et al., 2007; weight gain: FM $=150.4 \%$ vs. $\mathrm{PBM}=148.7 \%$; final weight: $\mathrm{FM}=31.4 \mathrm{~g}$ vs. $\mathrm{PBM}=$ $30.5 \mathrm{~g}$ ). Final weight and average daily gain of tilapia fed diet containing FM were similar (final weight $=273$ g; average daily gain $=1.73 \mathrm{~g}$ ) to fish fed a diet containing PBM (final weight $=248 \mathrm{~g}$; average daily gain = $1.57 \mathrm{~g}$; El-Sayed, 1998). 
The feed conversion rate model (Figure 2) show that the optimum level of replacement was estimated as $22.9 \%$ of FM replaced by PBM, with an FCR of 0.84 . When applying the $97.5 \%$ safe maximum to correct for under estimations of the quadratic model, the replacement level increases to $54.5 \%$ and FCR increases only 0.02 ; conversely, the cost of the feed decreases US $\$ 0.20$ per $\mathrm{kg}$ of diet (from US\$1.64 at $22.9 \%$ replacement to US\$ 1.44 at $54.5 \%$ ). El-Sayed (1998) reported that full replacement of FM by PBM impaired the FCR (100 $\% \mathrm{FM}=1.86 ; 100 \% \mathrm{PBM}=2.24)$ of Nile tilapia.

Protein efficiency ratio is a standard procedure for estimating the quality of protein ingredients based on the essential amino acid content and ratios of these amino acids and non-essential amino acids in each protein source. Dourado fed the 60\%FM40\%PBM diet utilized more efficiently the dietary protein than those fed the $100 \%$ PBM diet (Table 4). Differently, rainbow trout fed diets containing $30 \%$ and $40 \%$ PBM have experienced decreased efficiency of protein utilization comparatively to fish fed the control (0\% PBM), $10 \%$, and $20 \%$ PBM diets (Erturk and Sevgili, 2003). Differently from dourado and rainbow trout, the largemouth bass utilized dietary protein with similar efficiency regardless of the replacement level of FM by PBM (Tidwell et al., 2005). The protein efficiency ratio model is presented in Figure 3. The optimum level of PBM in the diet was $35.9 \%$, with a PER of 2.684 and a cost of protein in the feed of US\$1.56. The safe replacement level was $62.9 \%$, which decreased the PER to 2.617 and the feed protein cost to US\$ 1.38. Although the PER decreased only 0.067 , the cost of the feed decreased US\$ 0.18, a sizable decrease when considering a commercial setting. Differently from this study, tilapia fed diet with $100 \%$ PBM had similar PER values to fish fed $100 \%$ FM (1.55 vs. 1.70, respectively for PBM and FM, El-Sayed, 1998). Differences in results herein reported and those reported by El-Sayed (1998) are mostly due to the feeding habit of the fish, since dourado is a carnivore and tilapia an omnivore species. Consequently, tilapia is more adapted to digest and utilize feedstuffs of lesser quality.

The model for CM predicts that the optimum substitution level is $31.6 \%$, which gives a CM of US\$ 8.24 and a cost of protein in the feed of US $\$ 1.58$. When the safe level is considered, the replacement increases to $46.7 \%$, the CM decreases to US $\$ 8.03$, and the cost including feed decreases by US $\$ 0.10$. In addition to the

Table 5 - Regression analysis (M-estimation) of the parameter for the marginal contribution analysis $(\alpha=0.10)$.

\begin{tabular}{lcccrc}
\hline Parameter & $\begin{array}{c}\text { Degrees of } \\
\text { Freedom }\end{array}$ & Estimator & $\begin{array}{c}\text { Standard } \\
\text { Error }\end{array}$ & Chi-Square & Pr $>$ ChiSq \\
\hline Intercept & 1 & 7.342 & 0.7234 & 103.02 & $<0.001$ \\
$\mathrm{X}$ & 1 & 0.0568 & 0.034 & 2.79 & 0.0948 \\
$\mathrm{X}^{2}$ & 1 & -0.0009 & 0.0003 & 6.83 & 0.009 \\
Scale & 1 & 1.4173 & & & \\
\hline
\end{tabular}

graphic representation of the effect of replacement of FM by PBM in contribution margin, Table 5 presents the data for estimating the parameters for the equation. In similar conditions, Yamamoto et al. (2017) studied the replacement of FM by soybean meal (SBM) in diets for dourado and reported that to maximize profit, the ideal inclusion level of FM was $83.51 \%$ of the dietary protein. Similarly, this study registers that the ideal levels of FM would be $68.4 \%$, which is much lower compared to the $83.51 \%$ reported by Yamamoto et al. (2017), and this higher inclusion level of replacement protein source mainly results from the more balanced nutrient profile of PBM compared to the SBM. Even with worse FCR $(\mathrm{FM}=1.86$ vs. $\mathrm{PBM}=2.24, p<0.05)$, tilapia fed 100 $\%$ PBM had a better incidence cost (IC $=$ cost of $\mathrm{kg}$ of feed consumed / $\mathrm{kg}$ of fish produced; 3.47 ) and profit index $(\mathrm{PI}=$ value of fish crop / cost of feed consumed; 2.31) than fish fed $100 \% \mathrm{FM}$ ( $\mathrm{IC}=4.83$; PI $=1.65$ ), which translates to a lower cost of diet production and higher profit (El-Sayed, 1998). Hernández et al. (2007) simulated the impact of different production variables (water temperature, weight gain between two sampling points, and levels of dietary SBM) in the SGR or daily intake ratio of sharpsnout seabream, and concluded that $60 \%$ of the diet for sharpsnout seabream could be made from SBM without compromising profit, even though the feed consumption increased to sustain a similar growth rate. For gilthead sea bream, the optimum economic inclusion of SBM was $22 \%$, as higher levels would not increase profit mainly because of the relatively lower prices of the FM at the time the study was performed (Martinez-Llorens et al., 2007).

As a rule, the composition of animal protein sources vary to a great extent. Most of these differences are caused by the initial characteristics of raw materials (levels of degradation, microbial contamination, composition, etc.) and the processing conditions (excessive heat can destroy more nutrients - e.g. amino acids; additional removal of fat and water concentrates the protein and ash, etc.). Usually these characteristics of the product and processing conditions are not considered by authors even though a portion of the variability in the results could be explained by these peculiarities of each source of FM or PBM used. Dourado can use dietary PBM protein efficiently, but medium to high levels of replacement of FM by PBM reduced AFW, AWG, FCR, PER, and SGR. On the other hand, diets with approximately two thirds of FM and a third of PBM guarantee a better nutrient profile, and improve performance. Fish meal could be replaced by PBM at levels varying from 22.9 $\%$ to $35.9 \%$ when considering the optimal replacement level using the quadratic model, or from $40.9 \%$ to 62.9 $\%$ using the safe replacement level. If maximum profit and contribution margin are to be achieved, it is recommended replacing up to $31.6 \%$ of dietary FM with PBM if maximum profit. However, it is advisable to consider a safe replacement level, which is $46.7 \%$ of replacement of FM by PBM. 


\section{Authors' Contributions}

Conceptualization: Cyrino, J.E.P. Data acquisition: Donadelli, R.A. Data analysis: Cyrino, J.E.P., Donadelli, R.A., Aguilar, F.A., Sonoda, D.Y. Writing and editing: Cyrino, J.E.P., Donadelli, R.A., Aguilar, F.A., Sonoda, D.Y.

\section{References}

Abdel-Warith, A.A.; Russel, P.; Davies, S.J. 2001. Inclusion of a commercial poultry by-product meal as a protein replacement of fish meal in practical diets for African catfish Clarias gariepinus (Burchell 1822). Aquaculture Research 32: 296-305.

Allan, G.L.; Parkinson, S.; Booth, M.A.; Stone, D.A.J.; Rowland, S.J.; Frances, J.; Warner-Smith, R. 2000. Replacement of fish meal in diets for Australian silver perch, Bidyanus bidyanus. I. Digestibility of alternative ingredients. Aquaculture 186: 293310.

Association of Official Analytical Chemists - International [AOAC]. 1999. Official Methods of Analysis. 16ed. AOAC, Gaithersburg, MD, USA.

Borghesi, R.; Dairiki, J.K.; Cyrino, J.E.P. 2009. Apparent digestibility coefficients of selected feed ingredients for dourado Salminus brasiliensis. Aquaculture Nutrition 15: 453458.

Borghetti, J.R.; Canzi, C.; Fernandez, D.R. 1990. The influence of different levels of protein on the growth of dourado (Salminus maxillosus). Arquivos Brasileiros de Biologia e Tecnologia 33: 683-689 (in Portuguese, with abstract in English).

Braga, L.G.T.; Borghesi, R.; Cyrino, J.E.P. 2008. Apparent digestibility of ingredients in diets for Salminus brasiliensis. Pesquisa Agropecuária Brasileira 43: 271-274.

Burel, C.; Boujard, T.; Kaushik, S.J.; Boeuf, G.; Van Der Geyten, S.; Mol, K.A.; Kühn, E.R.; Quinsac, A.; Krouti, M.; Ribaillier, D. 2000. Potential of plant-protein sources as fish meal substitutes in diets for turbot (Psetta maxima): growth, nutrient utilization and thyroid status. Aquaculture 188: 363382.

Dairiki, J.K.; Borghesi, R.; Dias, C.T.S.; Cyrino, J.E.P. 2013. Lysine and arginine requirements of Salminus brasiliensis. Pesquisa Agropecuária Brasileira 48: 1012-1020.

Dozier III, W.A.; Corzo, A.; Kidd, M.T.; Tillman, P.B.; Branton, S.L. 2009. Digestible lysine requirements of male and female broilers from fourteen to twenty-eight days of age. Poultry Science 88: 1676-1682.

Dozier III, W.A.; Dale, N.M. 2005. Metabolizable energy of feedgrade and pet food-grade poultry by-product meals. Journal of Applied Poultry Research 14: 349-351.

El-Sayed, A-F.M. 1998. Total replacement of fish meal with animal protein sources in Nile tilapia, Oreochromis niloticus (L.) feeds. Aquaculture Research 29: 275-280.

Erturk, M.M.; Sevgili, H. 2003. Effects of replacement of fish meal with poultry by-product meals on apparent digestibility: body composition and protein efficiency ratio in practical diets for rainbow trout, Onchorynchus mykiss. Asian-Australasian Journal of Animal Sciences 16: 1355-1359.
Food and Agriculture Organization of the United Nations [FAO]. 2016. GLOBEFISH Highlights: A Quarterly Update on World Seafood Markets 4: 1-72.

Gaylord, T.G.; Rawles, S.T. 2005. The modification of poultry-by product meal for use in hybrid striped bass Morone chrysops $\times$ M. saxatilis diets. Journal of the World Aquaculture Society 36: 363-374.

Griffiths, W.E.; Hill, R.C.; Judge, G.G. 1993. Learning and Practicing Econometrics. John Wiley, NewYork, NY, USA.

Hardy, R.W. 2010. Utilization of plant proteins in fish diets: effects of global demand and supplies of fishmeal. Aquaculture Research 41: 770-776.

Hernández, M.D.; Martínez, F.J.; Jover, M.; García-García, B. 2007. Effects of partial replacement of fish meal by soybean meal in sharpsnout seabream (Diplodus puntazzo) diet. Aquaculture 263: 159-167.

Hertrampf, J.W.; Piedad-Pascual, F. 2000. Handbook on Ingredients for Aquaculture Feeds. Kluwer Academic, Dordrecht, Germany.

Huber, P.J. 1973. Robust regression: asymptotics, conjectures and Monte Carlo. Annals of Statistics 1: 799-821.

IndexMundi. 2014. Broiler meat (poultry) production by country in 1000MT. Available at: http://www.indexmundi.com/ agriculture/?commodity = broiler-meat\& [Accessed Mar 5, 2014].

Martinez-Llorens, S.; Monino, A.V.; Vidal, A.T.; Salvador, V.J.M.; Torres, M.P.; Cerda, M.J. 2007. Soybean meal as a protein source in gilthead sea bream (Sparus aurata L.) diets: effects on growth and nutrient utilization. Aquaculture Research 38: 82-90.

Meeker, D.L. 2009. North American rendering: processing high quality proteins and fats for feed. Revista Brasileira de Zootecnia 38: 432-440.

Pompeu, P.S. 2012. Permanent preservation rivers: an alternative for conservation of fish populations? = Rios de preservação permanente: uma alternaiva para a conservação da ictiofauna? Ação Ambiental 47: 12-14 (in Portuguese).

Rawles, S.D.; Fuller, S.A.; Beck, B.H.; Gaylord, T.G.; Barrows, F.T.; McEntire, M.E. 2013. Lysine optimization of a commercial fishmeal-free diet for hybrid striped bass (Morone chrysops $\times$ M. saxatilis). Aquaculture 396-399: 89-101.

Rawles, S.D.; Gaylord, T.G.; McEntire, M.E.; Freeman, D.W. 2009. Evaluation of poultry by-product meal in commercial diets for hybrid striped bass Morone chrysops $\circ \times$ M. saxatilis $\delta$, in pond production. Journal of the World Aquaculture Society 40: 141-156.

Rawles, S.D.; Riche, M.; Gaylord, T.G.; Webb, J.; Freeman, D.W.; Davis, M. 2006. Evaluation of poultry by-product meal in commercial diets for hybrid striped bass (Morone chrysops $q$ $\times$ M. saxatilis ${ }^{\jmath}$ ) in recirculated tank production. Aquaculture 359: 377-389.

Schwertner, V.; Diemer, O.; Higuchi, L.H.; Klein, S.; Boscolo, W.R.; Feiden, A. 2013. Replacement of fish meal by poultry viscera meal in the feed of Leporinus macrocephalus. Ciência Animal Brasileira 14: 318-322 (in Portuguese, with abstract in English).

Shapawi, R.; Ng, W.K.; Mustafa, S. 2007. Replacement of fish meal with poultry by-product meal in diets formulated for the humpback grouper, Cromileptes altivelis. Aquaculture 273: 118-126. 
Tavernari, F.C.; Lelis, G.R.; Vieira, R.A.; Rostagno, H.S.; Albino, L.F.T.; Oliveira Neto, A.R. 2013. Valine needs in starting and growing Cobb (500) broilers. Poultry Science 92: 151-157.

Teixeira, B.; Machado, C.C.; Fracalossi, D.M. 2010. Dietary protein requirement of dourado (Salminus brasiliensis) fingerlings. Acta Scientiarum Animal Sciences 32: 33-38 (in Portuguese, with abstract in English).

Tidwell, J.H.; Coyle, S.D.; Bright, L.A.; Yasharian, D. 2005. Evaluation of plant and animal source proteins for replacement of fish meal in practical diets for largemouth bass Micropterus salmoides. Journal of the World Aquaculture Society 36: 454-463.
Varian, H.R. 2010. Intermediate Microeconomics: A Modern Approach. W.W. Norton, New York, NY, USA.

Weingartner, M.; Zaniboni-Filho, E. 2010. Biology and dourado stock $=$ Dourado. p. 257-286. In: Baldisserotto, B.; Gomes, L.C., eds. Native species to aquaculture in Brazil = Espécies nativas para piscicultura no Brasil. 2ed. Editora UFSM, Santa Maria, RS, Brazil (in Portuguese).

Yamamoto, F.; Sonoda, D.Y.; Cyrino, J.E.P. 2017. Profit maximization in protein source replacement in feeds for juveniles of dourado. Revista iPecege 3: 49-58 (in Portuguese, with abstract in English). 